\title{
Problem-Based Learning Model for Teaching Writing: A Literature Review
}

\author{
Nurul Aryanti ${ }^{1}$, Welly Ardiansyah ${ }^{2}$, Murwani Ujihanti ${ }^{3}$ \\ State Polytechnic of Sriwijaya \\ E-mail: aryantinurul479@gmail.com
}

\begin{abstract}
Many researchers have claimed the success of the application of problem-based learning in many fields of study. This learning model is in line with the constructivist principles, in which students are in the centre of the learning process. Moreover, problem-based learning model provides the opportunity for students not only to develop their hard skills, but also soft skills. In addition, it also strives to help students become independent and self-regulated learners. This is one of the main advantages of applying the learning model. This article attempts to provide a short review of problem-based learning model in teaching writing. Furthermore, the discussion will also focus on the issue by looking at some explanation found in accounting for the needs of the learning model in the 21st century-language learning.
\end{abstract}

Keywords - Problem-based learning, application, teaching, writing

\section{INTRODUCTION}

\section{Background}

The advance of technology in the education system requires more challenging learning models that suit the needs of students. Absolutely, the success of the students in obtaining targeted learning outcome is not only the responsibility of the lecturer, but also the entire institution system involved. However, as a professional lecturer, making a decision in a learning model for his/her subjects will give a very significant result, not only for the students, but also for his/her ideal professional job responsibility. In other words, the success of the learning process begins with the choice of the suitable learning model.

One of the most used learning models is problem-based learning. Graaff (2003) claimed that it has enormous popularity all over the world. It is becoming an increasingly popular term in tertiary education and was first applied in business schools and medical schools in the hope that it would increase self-directed learning and improve their problem-solving skills (Barrows, 1983, Kwan, 2000). Moreover, problem-based learning continues to be used in diverse ways across different subjects and disciplines worldwide (Savin-Baden, 2003), science and engineering classrooms (Woods, 1985), humanities and social sciences (Duch, 2001). In his paper, Oguz- Unver and Arabacioglu (2011) state that there is not any study reporting significant negative findings about the outcomes of problem-based learning on knowledge and skills. Hence, it proves to be an alternative learning model.

There have been a lot of reports on successful results on the application of problembased in the language learning. One of them is in writing-skill learning. Nic et al (2010) state that there are double problems for EFL learners since the learners have to struggle on the acquisition of grammar, syntactic structure, vocabulary, rhetorical structure and the idiom of new language. 
Therefore, this paper is aimed at explaining briefly problem-based learning model in teaching writing.

\section{Problem-Based Learning Model}

There are some opinions related to the concept of problem-based learning. Problem-based learning is considered a student-centered instruction approach in which inspired students to apply critical thinking through simulated problems in order to study complicated multifaceted, and practical problems that may have or not have standard answers (Barrows, 1996).While, Hendry and Murphy in Oon-Seng Tan (2009) define it as a model that organizes learning around problem. In addition, problem-based learning is the learning that results from the process of working towards the understanding or resolution of a problem Barrows and Tamblyn (1980).

Therefore, problem is the centre in this learning model, as Graaff and Kolmos (2007) state that problem based learning is a learning organized around problems. In relation to the problem used in problem-based learning, Graaff and Kolmos (2003) propose that:

"The type of problem is dependent on the specific organization. Usually, the problems are based on real-life problems which have been selected and edited to meet educational objectives and criteria. However, it could also be a hypothetical problem. It is crucial that the problem serves as the basis for the learning process, because this determines the direction of the learning process and places emphasis on the formulation of a question rather than on the answer."

It is hoped that by exploring the real life problems as the basis for the learning process, students will see that learning and life take place in context and affect the kinds of solutions that available and possible (Baden, 2003). However, there are two different views concerning with the nature of problem stated by Savin-Baden and Major (2004), open-ended solutions, in which the students are free to choose and decide whatever the ways-out may be, and solving problem using particular knowledge has been taught.

Furthermore, as an instructional approach that challenges students to seek solutions to real world situations/problems in groups, problem- based learning provides students with opportunities to direct their own learning while developing critical thinking and evaluation skills through analysis of real-life situations/problems (Smith, 1995). This is in line with Duch et al (2001) that define problem-based learning as a pedagogical strategy, which uses real-world situations as the basis to development of content, knowledge, and problem solving skill.

Savery \& Duffy (1995) state that problem-based learning is a curriculum design that identified students not as passive recipients of knowledge but as problem solvers who could develop disciplinary knowledge and problem solving strategies to confront ill-structured problems that occur in the real world. Problem solving is also claimed to be developed through the activation of prior-learning in the problem-based learning environment (Schmidt, 1983).

\section{a. Characteristics}

Arends (2012) states that problem-based learning strives to help students become independent and self-regulated learners. Guided by teachers who reportedly encourage and reward them for asking questions and seeking solutions to real problems on their own, students learn to perform these tasks independently later in life. This is in line with Aydinly (2007) that claims that in problem-based learning, teacher acts as a coach for or facilitator of activities that students carry out themselves. The teacher does not simply present information or directly control the progress of work, instead they provide the students with appropriate problems to work on, assist them in identifying and accessing the materials and equipments necessary to solve the problems, gives necessary feedback and support during the problem solving process, and evaluates students' participation and, with the goal of helping them develop their problem-solving as well as their language and literacy skills. Therefore, in the PBL classroom, the instructor guides, probes, and support students' initiatives, rather than lectures, directs, or provides easy solutions (Duch et al, 2001).

In addition, the characteristics are also supported by Barrow (1997) that states the characteristics of the model as: (1) student centered, the students are motivated to be responsible on self-learning. Problem-based 
learning is also reported to give significant result to raise students' motivation in learning and effectively enhance students' translation skills (Huang and Wang, 2012). (2) problem-based, the problem to be used is an ill-structured problem, e.g. the problem in the real world. Enough information will be given to stimulate thinking process in the students' memory and this will involve inductive and horizontal reasoning, and deductive and vertical reasoning to generate hypothesis. (3) Problem solving, a problem will be used to stimulate effective and efficient development and reasoning skills. The teachers will guide the students at meta-cognitive level. At the early stage, there will be a modeling of problem solving process and teachers will reduce their role when students start to communicate and make argument with themselves and peers about what they think (4) self-directed, students can justify what they must learn and this is based on their task to solve the problem; (5) reiterative, when students are finished with self-directed learning (search of information needed to solve the problem) they will go back to the problems and will apply a new knowledge that they gain through problem solving. The experience that they gain will be used to construct new knowledge. (6) Collaborative, students will collaborate in the problem solving process and will identify learning issues. The student collaboration will occur during self-directed learning when students form a group to solve the learning issue which has been identified. It is in line with Blythe and Sweet (2008) that state when students work together, the free exchange of ideas in a problem-based learning environment often helps all students create better solutions and stories, as they gain ideas and learn from one another (Blythe \& Sweet, 2008), and the process shares much with theories related to constructivism. (7) self reflecting, when the problem is solved, students will make a selfreflection to new information, compared with new problem, make a reflection to face the same problem (for the future), to abstract a concept or a principle, and draw a mind map to show the connection of problem elements and connection of the reason. (8) Self-monitoring, student will monitor, evaluate the progress and self achievement. Self evaluation will be in the form of teacher response, peer group and other evaluation and; (9) authentic, all the required learning behavior in PBL includes all the required steps by students and it will be evaluated in real world situation.

Beside that, Norman and Schmidt (2000) claim that problem-based learning is challenging, motivating, enjoyable, and the process can construct an extensive and flexible knowledge base which is related to the multidisciplinary of problem-based learning. The process is enable students to develop effective problem-solving, self-directive, and life-long learning skills.

\section{The Application of Problem-Based Learning in Teaching Writing}

There are, of course, many ways to structure writing activities combining with problem-based learning (Trekles, 2012). In teaching writing, the activities can be done using the procedures of applying problem-based learning proposed by Arends (2012), Trekles (2012), and Delisle (1997). The first step is orienting students to the problem. In this step, students must engage in an authentic scenario that involves real-world problems (Savery \& Duffy, 1995). These problems are often multidisciplinary in nature and open-ended in that there is not necessarily one correct way to approach the problem or offer a solution. Therefore, all students have the same right and chance to give ideas related to the scenario before proposing some requirements on the problem solving (Aryanti, 2017), moreover, the problem should be interesting and challenging to provoke students' eagerness to find solutions.

The second step is organizing students for study/setting up the structure. This is the guideline of thinking process toward finding problem solving. In this step, the students are asked to explore information from media or books in order obtain the best solution to the problem they encountered. They should use four column headings as the guideline, ideas, facts, learning issues, and action plan. In the ideas column, they should write the ideas that come up in the brainstorming session for finding solution. The facts about the problem are recorded in the facts column. In the learning issues, they should write the questions that need more elaboration, definition, or research. While in action plan, the steps for solving problem are noted.

The third step is assisting independent and group investigation/producing a product or performance phase. In this step, the instructor 
serves as a guide during exploration and during the writing process, which includes providing insight into writing conventions as well as guiding students through the use of the virtual world, and leading them to useful resources. Scaffolding will consist of direct instruction, "hints," and suggestions as required by the situation. As students work in the simulation in a computer lab setting, the instructor should actively observe students as they work.

The fourth is producing a product of performance phase. The students expose their work results in the form of either product or performance. It can range from writing memo to making presentation before their classmates. The products or presentations are the objects of evaluation for the teachers. It is also strengthening students' understanding of the materials. Besides that, it enhances their knowledge that is acquired during finding the problem-solving process.

The fifth is reflection and debriefing/evaluating performance and the problem. When students have written their stories they will spend time in peer review, exchanging their writing and commenting on what they see. They must then reflect and make edits as needed. Near the end of the lesson, all students will come together as a class to briefly discuss their thoughts on the writing prompt, the virtual world, and what they enjoyed or did not enjoy about the learning experience. The completed stories will be assessed by a detailed rubric designed to evaluate their attainment of learning goals, their collaboration activities, and the quality and feasibility of their story. During peer review, students will use this same rubric to assess each other's work, as well as their own, as they make revisions prior to submitting a final draft.

Each expert working in problem-based learning has his/her own procedures. However, teachers can modify them based on their learning outcomes. As a teaching methodology, probembased learning addresses a primary goal of education; that is to develop students who are effective problem solvers. The problem-based learning curriculum delivery model recognizes the need to develop students to be effective problem solver and assist with the acquiring the skills and knowledge associated with a particular profession. Ideally, the problem-based learning process culminates with students possessing skills and abilities that adequately prepare them for professional occupations where critical thinking, individual and group work is expected and complex problem solving skills are essential for success (Ramsay and Sorrel, 2006; Ulger, 2018; Zabit, 2010).

In response to the challenges of the twentyfirst century with its complex environmental, social and economic pressures, young people are required to be creative and innovative. Therefore, the application of problem-based learning model is claimed to be one of the suitable models to apply because the model foster not only team-work, but also critical thinking skills (Schon, 1983; Spence, 2001; Margetson, 1997; Uden \& Beaumont, 2006;Thomson, 2011; Barrow, 1996; Aryanti, 2017).

\section{Conclusions}

Problem-based learning has been used in many fields of study, including language. It is a model that organizes learning around problem and learning that results from the process of working towards the understanding or resolution of a problem, provides students with opportunities to direct their own learning while developing critical thinking and evaluation skills through analysis of real-life situations/problems. There are different procedures in applying the model, however, teachers can modify them depending on the needs or the outcome of the learning. Problem-based learning is considered as one of the suitable learning models to be applied in the $21^{\text {st }}$ century learning, for it strives to help students become independent and self-regulated learners.

\section{REFERENCES}

[1] Aryanti, N. 2017. The Effect of Learning Model and Critical Thinking Ability on Students'Argumentative Writing Skills. Dissertation (Jakarta, State University of Jakarta).

[2] Arends, Richard. 2012. Learning to Teach. New York: McGraw Hills Companies.

[3] Aydinli, Julie Mathews. 2007. Problem-Based Learning and Adult English language Learners. Washington DC: Centre for Adult English Language Acquisition, Centre for Applied Linguistics. April.

[4] Ayşe OĞUZSertaç ARABACIOĞLU. 2014. A Comparison of Inquiry-Based Learning (IBL), Problem-Based Learning and ProjectBased Learning in Science Education. Academia Journal of Educational Research 2(7): 120-128.

[5] Barrows, H. S. 1996. Problem-Based Learning in Medicine and beyond: A Brief Overview. New Direction for Teaching and Learning, 68, 3-12.

[6] Barrows, H.S. and Tamblyn, R.M. (1980). Problem-based learning: An approach to medical education. New York: Springer Publishing Company, Inc. 
[7] Blythe, H., and Sweet, C. 2008. The writing community: A new model for the creative writing classroom. Pedagogy: Critical Approaches to Teaching Literature, Language, Composition, and Culture, 8(2), 305-325. Doi: 10.1215/15314200-2007-042.

[8] De Graaff, Erik and Anette Kolmos. The Characterictics of ProblemBased Learning. Retrieved from http//www.ijee.ie, Volume 19-5, ijee1450.

[9] Delisle, Robert. 1997 How to Use Problem-Based Learning in the Classroom.USA: Library of Congress Cataloging-in-Publication Data.

[10] Duch, B.J S.E., and Allen, D.E. 2001. The Power of Problem-Based Learning. VA: Sylus.

[11] Huang, Kuo-shu and Tzu-Pu Wang. Applying Problem-Based Learning (PBL) in University English Translation Classes. The Journal of International Management Studies. Vol 7 (1), April 2012.

[12] Margetson, D. 1997. Why is Problem-Based Learning A Challenge? In D. Boud, \& G. Feletti (Eds). The Challenge of Problem-Based Learning (pp. 117-124). London: Kogan Page Limited.

[13] Nik, Y. A., Badariah S., Muhmad Ch., Kamaruzaman J., and Hasif H. 2010. 'The writing performance of udergraduates in the University of Technology Mara, Trengganu, Malaysia'. Journal of Language and Culture. 1 (1), 8-14.

[14] Savin-Baden, M and Mayor, CH. 2004. Foundations of ProblemBased Learning. Bodmin Cornwall. MPG Books, Ltd.

[15] Savin-Baden, Maggi. 2003. Facilitating problem-Based Learning:Illuminating perspectives. England: McGraw-Hill Education.

[16] Savery, J.R., and Duffy, T.M. 1995. Problem-based learning: An instructional model and its constructivist framework. In B. Wilson (Ed.), Constructivist learning environments: Case studies in instructional design (pp. 135-148). Englewood Cliffs, NJ: Educational Technology Publications.

[17] Savery, J. 2006. Overview of problem-based learning: Definitions and distinctions. Interdisciplinary Journal of Problem-based Learning, 1(1), 9-20.

[18] Schon, D. 1983. The Reflective Practitioner. How Professionals Think in Action. New York: Basic Books.

[19] Spence, L. 2001. Problem-Based Learning: Lead to Learn, Learn to Lead, Problem-Based Handbook, Penn State University, School for Information Sciences and Technology.

[20] Thomson, C. 2011. Critical Thinking Across the Curriculum. Process Over Output. International Journal of Humanities and Social. Vol. 1 No. 9 (Special Issue-July 2011).

[21] Trekles, Anastasia M. Creative Writing, Problem-Based Learning, and Game-Based Learning Principles. The International Society for Technology in Education (ISTE) Conference, June 25, 2012.

[22] Tan, Oon-Seng. 2009. Problem-Based Learning and Creativity. Singapore: Cengage Learning Asia Pte Ltd. Uden, L., \& Beaumont, C. 2006. Technology and Problem-Based Learning London: Information Science Publishing.

[23] Uden, L., and Beaumont, C. 2006. Technology and Problem-Based Learning London: Information Science Publishing.

[24] Ulger, K. 2018. The Effect of Problem-Based Learning on the Creative Thinking and Critical Thinking Disposition of Students in Visual Arts Education. Interdisciplinary Journal of Problem-Based Learning. Volume 12 (1) Article 10.

[25] Zabit, M.N. MD. 2010. Problem Based- Learning on Students' Critical Thinking Skills in Teaching Business Education in Malaysia: A Literature Review. American Journal of Business Education: June, Volume 3 (6). 